\title{
Successful Pediatric ABO-Incompatible Kidney Transplantation without Pretransplant Plasmapheresis: Report of a Case
}

\author{
Department of Surgery ${ }^{1}$ and Research Institute for Transplantation ${ }^{2}$, \\ Department of Laboratory Medicine ${ }^{3}$, Yonsei University College of Medicine, Seoul, Korea
}

\begin{abstract}
A-Lan Lee, M.D. ${ }^{1,2}$, Hyun Ok Kim, M.D. ${ }^{3}$, Kyu Ha Huh, M.D. ${ }^{1,2}$ and Myoung Soo Kim, M.D. ${ }^{1,2}$
Immunologic responses of infants and younger children differ from those of adults. Therefore, application of different pretransplant strategies for antibody depletion in younger ABO-incompatible transplant recipients is appropriate. A 12-month-old male infant with end stage renal disease after acute tubular necrosis was scheduled to undergo kidney transplantation from an $\mathrm{ABO}$-incompatible living donor. He did not undergo pretransplant plasmapheresis, as the titer of the anti-ABO antibody was less than $1: 4$. After kidney transplantation, posttransplant renal function and anti-ABO titers were stable until posttransplant 2 years.
\end{abstract}

Key Words: Pediatric kidney transplantation, $\mathrm{ABO}$-incompatible kidney transplantation, Plasmapheresis 중심 단어: 소아 신이식, $\mathrm{ABO}$ 혈액형 부적합, 혈장교환술

\section{Introduction}

ABO-incompatible kidney transplantation has been shown to be a valid alternative even for children with end stage renal disease. In Japan, 52 pediatric cases of ABO-incompatible kidney transplantation have been reported(1). All pediatric patients in our country underwent the conventional transplant protocol with pretransplant plasmapheresis, similar to adult patients. However, we experienced the case of an infant who underwent ABO-incompatible pediatric kidney transplantation without pretransplant plasmapheresis.

\section{Case Report}

The patient was a 12-month-old, $9.7 \mathrm{~kg}$ male infant born at intrauterine period (IUP) $38+2$ weeks weighing $2.65 \mathrm{~kg}$, who was delivered by cesarean section due

Correspondence : Myoung Soo Kim, Department of Surgery, Yonsei University College of Medicine, 50 Yonseiro, Seodaemoon-gu, Seoul 120-752, Korea Tel: +82-2-2228-2123, Fax: +82-2-313-8289 E-mail: ysms91@yuhs.ac

Received : January 9, 2014, Revised : February 27, 2014, Accepted : February 27, 2014 to breech presentation. He had imperforate anus and an umbilical cord anomaly (1 artery, 1 vein). He underwent a mini Pena operation 2 days after birth. However, on day 3 after birth, he was re-operated on due to panperitonitis caused by sigmoid colon perforation. Immediately after the operation, he progressed to disseminated intravascular coagulation, which was required fresh frozen plasma and antithrombin III, due to sepsis and massive transfusion. During the postoperative period, he suffered acute tubular necrosis, resulting in severe acidosis and oliguria. Unfortunately, his renal function did not recover. After 5 months, he began peritoneal dialysis, but he did not tolerate this well because of frequently nonfunctional drainage. Therefore, his treatment was changed to hemodialysis, and his parents requested kidney transplantation.

\section{1) Donor selection}

The infant's ABO blood type was A positive with A1 subgroup. His father was the same blood type A positive and his mother was $\mathrm{AB}$ positive. We first performed an immunoassay on his father. The panel reactive antibody (PRA) screening report by bead-based immunoassay (single Ag flow bead by Luminex platform) showed a positive reaction for anti-human leu- 
kocyte antigen (anti-HLA) class II, and the complement-dependent cytotoxicity (CDC) crossmatch showed positive on $\mathrm{T}$ cell crossmatch (by CDC-NIH, Time long, and anti-human globulin methods) and $\mathrm{B}$ cell crossmatch (by CDC-warm and cold methods), respectively. We decided to perform ABO-incompatible kidney transplantation from the patient's mother. The infant had one-haplotype mismatch in HLA in comparison with his mother. The PRA identification report showed $0 \%$ and $43 \%$ on class I and class II (DSA-DR4, MFI 5978), respectively, and the CDC crossmatch showed all negative results.

\section{2) Recipient management in pretransplant period}

Pretransplantation anti-B antibody titer in the infant was $1: 4$ for IgM and less than $1: 2$ for IgG. Measurement of anti-B antibody titer was determined by testing serial two-fold dilutions of the serum of patients with commercially made B indicator red cells(2).

The infant did not undergo plasmapheresis to re-

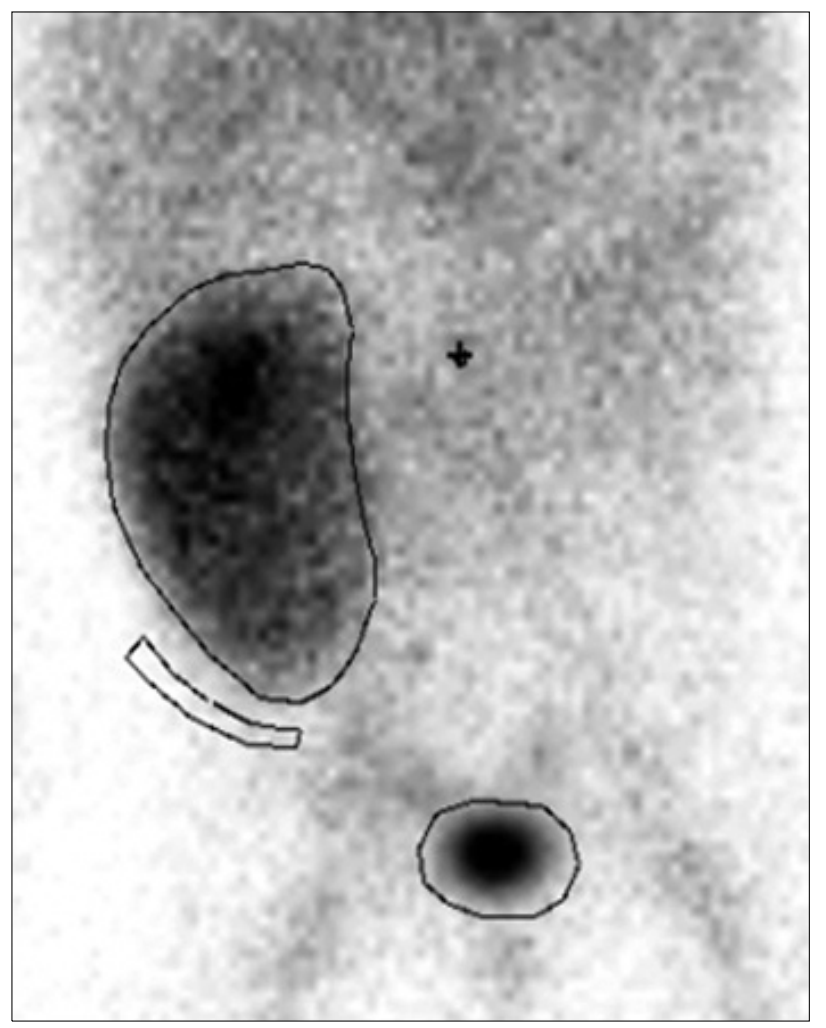

move the anti-B antibody. The pretransplant B-cell depletion was performed by a single dose of rituximab $\left(375 \mathrm{mg} / \mathrm{m}^{2}\right)$ on 4 day preoperatively and we identified complete elimination of B-cell by CD20 marker before transplantation. The pretransplant immunosuppressive protocol consisted of tacrolimus $(0.05$ $\mathrm{mg} / \mathrm{kg}$, twice a day) and prednisolone $(0.5 \mathrm{mg} / \mathrm{kg}$ per day), administered 7 days before the surgery.

\section{3) Recipient management in posttransplant period}

Living donor kidney transplant was performed using a trans-peritoneal approach. The duration of the procedure was 5 hours and 30 minutes. During the operation, blood loss of $120 \mathrm{~mL}$ was observed, and we transfused the infant with $270 \mathrm{~mL}$ filtered irradiated $\mathrm{O}$ positive packed RBCs. For the posttransplant immunosuppressive protocol, basilixumab (10 mg) was used for induction therapy on the operative day and on postoperative day 4 , and tacrolimus and prednisolone were used for maintenance therapy. We did not
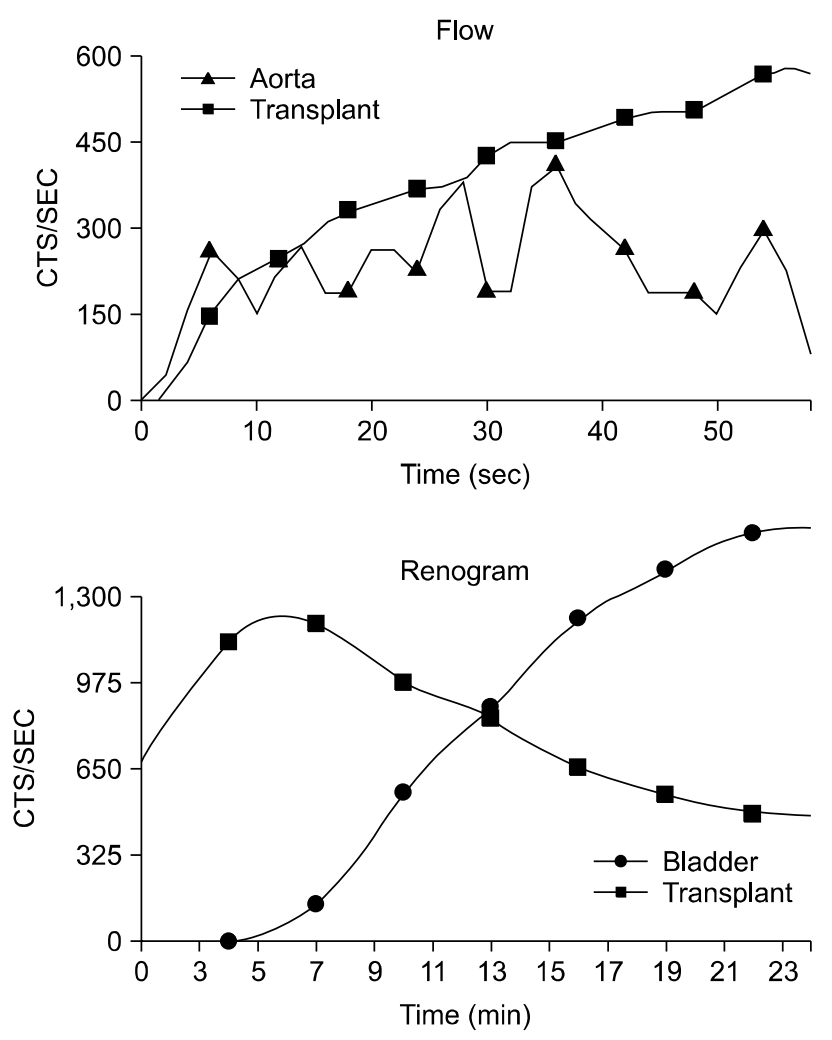

Fig. 1. Renogram on postoperative day 8. Normal cortical transit and renal excretion of the radiotracers. Transplanted kidney shows within normal limits of blood flow and uptake. 
use anti-metabolite, because of difficult to dose adjustment in pediatrics and prevention of infection. The postoperative course has been remarkably uneventful, and the patient has not experienced delayed graft function nor rejection episodes (Fig. 1). Anti-B antibody titers were maintained at less than $1: 4$ for 2 years posttransplant without additional plasmapheresis (Table 1). We changed the dose of immunosuppressive medications during postoperative periods. The use of steroid decreased after posttransplant 3 months, we withdrawal steroid since 1 year. The trough levels of tacrolimus were 8 to $12 \mathrm{ng} / \mathrm{mL}$ within 1 year, since then 3 to $5 \mathrm{ng} / \mathrm{mL}$. During the posttransplant 2 years, the patient has maintained good renal function with no other problems.

\section{Discussion}

The immune responses of infants are different from those of adults. The humoral immune responses to mismatched blood group antigens do not seem to occur in children (infants, in particular)(3). In contrast to the capacity to respond to T-dependent protein antigens (i.e., proteins, such as major histocompatibility complex antigens), a well-documented aspect of neonatal immaturity that occurs as part of normal human development is deficient $\mathrm{B}$ cell responsiveness to T-independent antigens (i.e., carbohydrates, such as blood group antigens)(4-7). This is reflected by impaired infant antibody responses to polysaccharide antigens, such as those carried by various encapsulated bacteria. This deficiency includes development of "natural" antibodies to nonself $\mathrm{A} / \mathrm{B}$ histo-blood group antigens (is- ohemagglutinins). ABO isohemagglutinins develop as a presumed immunologic cross-reaction to similar carbohydrate epitopes expressed in nonpathologic intestinal flora(8). Sometimes, young adult has low antibody titer. However, we presume it is different to neonatal immunity, although we did not perform plasmapheresis to young adult (17 years old) with low antibody titer. For reasons not fully elucidated, isohemagglutinin production does not begin until after 5 to 6 months of age, with wide variation in the normal population in both age at onset of antibody production and eventual titers(9).

This unique window of opportunity allows for successful transplantation across the $\mathrm{ABO}$ barrier in infants without risk of hyperacute rejection. Although the anti-ABO antibody titers are different according to age, if the titer is less than $1: 4$ due to the immaturity of humoral immunity, less aggressive transplantation methods could be considered, such as a pretransplant protocol without plasmapheresis to remove anti-ABO antibodies. If plasmapheresis is not performed prior to transplantation, the infant has the advantage that volume depletion has not occurred.

In adults, it would be expected that if antibodydepletion methods allowed short-term survival of ABOincompatible grafts, accommodation might ensue in the long-term. In contrast to adults, West(10) demonstrated that in infants, graft acceptance occurs mainly because of B-cell-mediated immunological tolerance. In these pediatric recipients, antibodies to the donor blood group antigens are often present in very low titers or not at all detectable both in the circulation and on the graft. B-cell tolerance develops upon exposure

Table 1. Anti-B antibody titer and renal function

\begin{tabular}{|c|c|c|c|c|c|}
\hline & \multirow{2}{*}{ Pretransplant } & \multirow{2}{*}{ Discharge day (POD \#10) } & \multicolumn{3}{|c|}{ Postoperative } \\
\hline & & & $6 \mathrm{mo}$ & $1 \mathrm{yr}$ & $2 \mathrm{yr}$ \\
\hline Anti-B IgM & $1: 4 \mathrm{P}$ & $1: 1 \mathrm{P}$ & $\mathrm{N}$ & $\mathrm{N}$ & $\mathrm{N}$ \\
\hline Anti-B IgG & $<1: 2 \mathrm{~N}$ & $<1: 2 \mathrm{~N}$ & $<1: 2 \mathrm{~N}$ & $<1: 2 \mathrm{~N}$ & $<1: 2 \mathrm{~N}$ \\
\hline BUN (mg/dL) & 60.6 & 16.1 & 21.0 & 17.5 & 20.9 \\
\hline Creatinine $(\mathrm{mg} / \mathrm{dL})$ & 2.39 & 0.22 & 0.53 & 0.50 & 0.44 \\
\hline
\end{tabular}

Abbreviations: POD, postoperative day; IgM, immunoglobulin M; IgG, immunoglobulin G; P, positive; N, negative; BUN, blood urea nitrogen. 
of the immature immune system to donor $\mathrm{A} / \mathrm{B}$ antigens, resulting in decreased evolution of antibody production with increasing age compared with normal children and with infant recipients of ABO-compatible grafts(11). This B-cell tolerance seems to be specific to the donor blood group antigens and not mediated by B-cell anergy, as the recipient $B$ cells are fully capable of producing antibodies against third-party and non-speci fic oligosaccharide antigens(12).

Tyden et al.(13) reported on 10 pediatric patients who underwent $\mathrm{ABO}$ incompatible kidney transplantation. Preoperatively, the immunosuppressive protocol consisted of one dose of rituximab $\left(375 \mathrm{mg} / \mathrm{m}^{2}\right)$, given four weeks before immunoadsorption. It was followed by a conventional triple-drug immunosuppressive protocol consisting of tacrolimus, mycophenolate mofetil, and prednisolone. In 3 of the 10 infants, the antibody titer was $1: 2$ or less, and the preoperative plasmapheresis sessions were therefore canceled. One dose $(0.5 \mathrm{~g} / \mathrm{kg})$ of intravenous immunoglobulin was given following the last of the preoperative plasmapheresis sessions. However, because they were uncertain about the infants' antibody response to the massive antigen expression of the adult kidney, they did perform the three postoperative adsorptions in the first two cases, but because they did not observe any antibody rebound, the plasmapheresis was omitted in the third case. They have not experienced any rejection episodes related to rebound of $\mathrm{ABO}$ antibodies.

We experienced a single case of ABO-incompatible living donor kidney transplantation in which the infant did not undergo plasmapheresis prior to transplantation. During the 2 years since the operation, anti-B antibody titers have not elevated. Experience with pediatric ABO-incompatible kidney transplantation is still limited to a few cases, and long-term follow-up is needed. However, as we previously mentioned, infants have immaturity of their immune systems until they are exposed to the environment adequately, and B-cell tolerance develops in cases of ABO-incompatible transplantation. This has been seen particularly in heart transplantation studies(10-12). Therefore, we could consider that infants and younger children have different immunologic responses compared with adults.

Consequently, we should apply less aggressive strategies for antibody depletion in the pediatric ABO-incompatible patients according to pretransplant anti$\mathrm{ABO}$ antibody titers, as unique distinctive features.

\section{REFERENCES}

1) Shishido S, Hyodo YY, Aoki Y, Takasu J, Kawamura T, Sakai KK, et al. Outcomes of pediatric ABO-incompatible kidney transplantations are equivalent to $\mathrm{ABO}-\mathrm{com}-$ patible controls. Transplant Proc 2012;44:214-6.

2) Roback JD, Combs MR, Grossman BJ, Hillyer CD. Technical manual. 16th ed. Bethesda, MD: American Association of Blood Banks; 2008.

3) West LJ, Pollock-Barziv SM, Dipchand AI, Lee KJ, Cardella CJ, Benson LN, et al. ABO-incompatible heart transplantation in infants. N Engl J Med 2001;344:793800.

4) Klinman NR. The "clonal selection hypothesis" and current concepts of B cell tolerance. Immunity 1996;5:18995.

5) Cadoz M. Potential and limitations of polysaccharide vaccines in infancy. Vaccine 1998;16:1391-5.

6) Hartley SB, Crosbie J, Brink R, Kantor AB, Basten A, Goodnow CC. Elimination from peripheral lymphoid tissues of self-reactive B lymphocytes recognizing membrane-bound antigens. Nature 1991;353:765-9.

7) Hartley SB, Cooke MP, Fulcher DA, Harris AW, Cory S, Basten A, et al. Elimination of self-reactive B lymphocytes proceeds in two stages: arrested development and cell death. Cell 1993;72:325-35.

8) Springer GF, Horton RE. Blood group isoantibody stimulation in man by feeding blood group-active bacteria. J Clin Invest 1969;48:1280-91.

9) Fong SW, Qaqundah BY, Taylor WF. Developmental patterns of $\mathrm{ABO}$ isoagglutinins in normal children correlated with the effects of age, sex, and maternal isoagglutinins. Transfusion 1974;14:551-9.

10) West LJ. B-cell tolerance following ABO-incompatible infant heart transplantation. Transplantation 2006;81:3017.

11) West LJ. ABO-incompatible hearts for infant transplantation. Curr Opin Organ Transplant 2011;16:548-54.

12) Fan X, Ang A, Pollock-Barziv SM, Dipchand AI, Ruiz $\mathrm{P}$, Wilson G, et al. Donor-specific B-cell tolerance after ABO-incompatible infant heart transplantation. Nat Med 2004;10:1227-33.

13) Tyden G, Kumlien G, Berg UB. ABO-incompatible kidney transplantation in children. Pediatr Transplant 2011;15: $502-4$. 